\title{
CORPORATE HISTORY CULTURE AND USEFUL INDUSTRIAL PAST: A CASE STUDY ON HISTORY MANAGEMENT IN FINNISH COTTON COMPANY PORIN PUUVILLA OY
}

\author{
Anna Sivula
}

\begin{abstract}
Histories are used and produced for several reasons and purposes. History culture consists of the entirety of generations, modifications, transformations and utilisations of the images of the past. This article is concerned with corporate history culture that is manifested in commissioned company histories and other representations of company history.

History culture is always oriented to the future. Corporate history culture developed out of the demand in companies, not within universities. I clarify, in the light of a microhistorical case of Porin Puuvilla Oy, how and why different actors select one past to be historicised and leave another to be obsolete.

I open my contribution with an introduction to the concepts and practices of corporate history culture and history management. Then I move on to the case study and analyse the way that practice and representations of corporate history culture changed between 1948 and 1973. As my methodological contribution, I introduce the analytical four-field of the internal and external dimensions of history management. I conclude the article with a discussion of the corporate history culture in the context of the concepts of retro and nostalgia.
\end{abstract}

Keywords: business history, company histories, corporate history culture, history management, nostalgia, Porin Puuvilla Oy, retro, use of history

\section{CORPORATE HISTORY CULTURE AND BUSINESS HISTORY: THE DEMAND FOR, AND THE USE OF, COMPANY HISTORIES}

Marc Bloch opened his famous essay The Historian's Craft by asking: "What is the use of history?" (Bloch 1997: 37; Bloch 1937: 3, 15). This article is a study about how commissioned company histories are produced and utilised.

I am, however, more interested in the use of different kinds of histories than in their quality. I begin my article with a short introduction to some of the key historiographical concepts, business history and corporate history culture. I analyse history management and corporate history culture in the light of the microhistorical case of Porin Puuvilla Oy (Pori Cotton Ltd). Porin Puuvilla 
Oy was founded in 1898 under the name of Björneborgs Bomullmanufaktur Aktiebolaget. The name was coined after a bankruptcy and changed to A.B. Björneborgs Bomull-Porin Puuvilla O.Y., and after another bankruptcy to Oy Porin Puuvilla-Björneborgs Bomull Ab. After the 1920s, the company used the name Porin Puuvilla Oy (Sivula 2013: 139-150). In the beginning, the enterprise was financed by local investors. In the 1950s, Porin Puuvilla Oy had already grown into a textile manufacturer with more than 3000 employees. The company merged into another textile company, Finlayson Oy, in 1974. Finally, all the textile industrial activities at the factory of Porin Puuvilla Oy ended in 1994.

I here discuss how the practices and representations of corporate history culture changed during the life of the company and during the period of the downshifting of the merged company. In addition, I pose the question of how useful the concepts retro and nostalgia are to a researcher who is trying to understand the culture behind company histories.

History is a representation of the absent past. The past is both presented and re- (meaning 'again') presented. History provides a proven interpretative description of what has happened (Ricoeur 2000: 169-170, 302), and is therefore considered to be a "true story" until proven to be false. History is useful, and therefore histories are used and produced for several reasons and purposes. History culture consists of the entirety of generations, modifications, transformations and utilisations of the images of the past. ${ }^{1}$ History culture is an umbrella term that refers to all types of use, production, formation and transmission of historical images (Salmi 2001: 135).

This article is concerned with corporate history culture, manifested in commissioned company histories and other representations of company history.

Corporate history has developed out of the demand within companies, not within universities. The tradition of commissioned company histories is not rooted in the academic tradition of business history, but it surely is an emerging institutional form of knowledge production. Over the last two decades, diverse institutions, companies and organisations have commissioned projects of historical research at universities or at other public research institutes (Ponzoni \& Boersma 2011: 123-124; Karonen \& Lamberg \& Ojala 2000a).

The first chair of business history was established at Harvard in 1927 (Fridensen 2008: 9). ${ }^{2}$ Business history has been primarily positioned as a subdiscipline of economic history, but recently there have also been some pleas for a more organisational cultural approach (Lipartito 2007: 620). There is a further growing demand for corporate history. According to Ponzoni and Boersma (2011: 123), corporate history is a "specific branch of business history, that is, in a way, a more narrowed, focused 'genre' of business history". ${ }^{3}$ 
Until quite recently, commissioned company histories were not regarded as proper history but rather as applied history. Commissioned historians were certainly not the most respected ones among professional historians. Coleman remarks, sarcastically, that academic historians used to undertake this kind of "journalistic hack-work" in order "to supplement income otherwise come from more reputable writings" (Coleman 1992: 208). Ponzoni and Boersma have, during this current decade, noted a change in the social position of the commissioned business historian. An important reason for this change lies in the new mentality of history departments, primarily centred on knowledge transfer ${ }^{4}$ Commissioned histories are, at the end of the day, financed histories. The new modes of university governance and the new economic goals and motives in the political discourse on science and education have reinforced commissioned historians as a new group of professionals within the community of European universities (Ponzoni \& Boersma 2011: 131). Additionally, in 2013, many business historians are interested in company case studies, whether they are commissioned or not. ${ }^{5}$

In the year 2000, Finnish historians Petri Karonen, Juha-Antti Lamberg and Jari Ojala released in Historiallinen aikakauskirja (Historical Journal) a discussion of the role of business historians and Finnish business histories (Karonen \& Lamberg \& Ojala 2000a), with the aim of promoting a new kind of business history (Karonen \& Lamberg \& Ojala 2000b: 263). They argued that Finnish historians had not yet noticed the growing importance of businesses and entrepreneurship in society. The business histories were then studied separately, each researcher working in his own ivory tower, without any common denominator to link their work. Karonen, Lamberg and Ojala were aiming to link Finnish business historians to the international framework of academic business history and thereby promote a new type of business historical approach, with an emphasis on the economic history of private enterprises (Karonen \& Lamberg \& Ojala 2000a).

Nonetheless, they received a very spiteful answer from Jyrki Vesikansa, a professional company historian and journalist, who defended the traditional narrative form of company history. According to Vesikansa, narrative company histories were, at their best, critical, analytical, interesting and reliable, and useful for both scholars and the commissioners (Vesikansa 2000a: 161-162). Karonen, Lamberg and Ojala replied to Vesikansa that they were not trying to devalue company histories, but instead promote an international concept of business history (Karonen \& Lamberg \& Ojala 2000b: 263). In 2001, Ojala continued with reports of a round table discussion about the possibility of setting up a Finnish business history unit with international standards. One of the main themes of the discussion was the role, reliability and quality of 
Finnish commissioned company histories (Ojala 2001: 220-223). It seems to me that the role and status of commissioned company histories was important for the future of academic business history in Finland. The undertone of this discussion about the nature of Finnish company histories was not very upto-date, and it was surprisingly similar to the European discussions from the early $1900 \mathrm{~s}$, about whether history is an art or a science. ${ }^{6}$ In the mental map of Finnish economic historians, in 2000, the practice of writing commissioned company histories was, and perhaps still is, situated outside of the academic business history approach.

The status of company histories varies according to national business history traditions. In the USA, company histories are included in business history. ${ }^{7}$ In Great Britain, however, the relationship between commissioned company histories and business history has already been discussed. When in the late 70s British academic business historians were gathering financial support from their business life stakeholders, they argued: "Company history is to business history as personal biography and individual monographs are to political history" (Coleman 1992: 203). And yet, when in the early 1980s the new unit was funded and functioning, an orthodox historian looked upon commissioned histories with disapproval, stating that they were "largely devoid of any scholarly value", and they consisted "primarily of reminiscences and anecdotes" (ibid.: 205). ${ }^{8}$

\section{IS CORPORATE HISTORY CULTURE ALWAYS A FIELD OF RETRO AND NOSTALGIA?}

The current discussions on history culture have recently been dominated by two concepts: one of being about retro and the other about nostalgia. These concepts might help to open some new aspects about corporate history culture. If the commissioned histories consist merely of reminiscences and anecdotes, are they to be understood in terms other than those of an economy oriented business historian?

In 2011, Simon Reynolds introduced the idea of "retromania". According to Reynolds, the first ten years of the 21 st century turned out to be the "Re"-Decade. The popular culture of the early 2000s was dominated by the re- prefix: revivals, reissues, remakes, recycling and re-enactments. For Reynolds it was also a decade of retrospection. Every year brought a fresh spate of anniversaries, celebrated with biographies, memoirs, histories, and other commemorative publications (Reynolds 2011: xi; Suominen 2008). In my case, the corporate history culture of Porin Puuvilla Oy vanished before the era of retromania had even begun. 
And what about nostalgia? Robert Robertson has traced how the sentiment of nostalgia in the late 1800s took the form of "wilful nostalgia", and how it, in the 1960s, was reborn into a new kind of "consumerist-simulational nostalgia", a yearning for escape from the hectic modern world of new consumer goods and other novelties (Robertson 1992: 46-55). This kind of nostalgia might have played a certain role in corporate history culture from the 1960s onwards. In the late 1970s, sociologist Fred Davis approached nostalgia from the point of view of concept, identity, life cycle, art, and society. He made a distinction between first-order nostalgia, which is nostalgia as a simple experience, second-order or reflexive nostalgia, which is a more reflected form of thought and feelings, and, finally, third-order or interpreted nostalgia, which includes an effort to objectify feeling with some analytically oriented questions concerning its sources (Davis 1979: 17-24) These applications might be worth of a closer look, when researching corporate history culture.

Arjun Appadurai, for his part, introduced a new kind of nostalgia in the mid-1990s. He named it "ersatz nostalgia" or armchair nostalgia, "a nostalgia without lived experience or collective historical memory" (Appadurai 1996: 78). This armchair nostalgia is most often considered to be a symptom of the cultural crisis caused by western consumer culture. Svetlana Boym in her works drew a distinction between the concepts of restorative and reflective nostalgia. According to Boym, restorative nostalgia is based on a transhistorical reconstruction of a lost home, while reflective nostalgia, on the contrary, delays the homecoming "wistfully, ironically, desperately". Restorative nostalgia "protects the absolute truth, reflective nostalgia calls it into doubt" (Boym 2001: XVIII). According to Boym, restorative nostalgia "manifests itself in total reconstructions of monuments of the past, while reflective nostalgia lingers on ruins, the patina of time and history, in the dreams of another place and another time" (ibid.: 41). "Restorative nostalgia knows two main narrative plots - the restoration of origins and the conspiracy theory" (ibid.: 43). "Restorative nostalgia has no use for the signs of historical time - patina, ruins, cracks, imperfections" (ibid.: 45). "Reflective nostalgia, on the other hand, can be ironic and humorous. It reveals that longing and critical thinking are opposed to one another, as affective memories do not absolve one from compassion, judgement or critical reflection" (ibid.: 49-50). 


\section{WHY ARE COMMISSIONED COMPANY HISTORIES WRITTEN AND WHO WRITES THEM?}

I have named the practical aspect of corporate history culture history management. ${ }^{9}$ Management research, after the Second World War, turned away from history; however, historical thinking is slowly making a comeback. Business historians have continued research into a few fields of management studies, and, primarily, into the field of international business or that of management history, which is the history of the development of production systems, such as Taylorism and Fordism (Kipping \& Üsdiken 2007: 97, 99). History management is neither one of these. History management refers to the use of histories for managerial purposes.

Histories are produced in order to explain conduct in an unpredictable future. What I am attempting to do here is to clarify the who, how and why in business life, when one selects one past to be historicised, and leaves another past to be obsolete.

The subject of how and what kind of history is used for management purposes demands a case study. History management seems to be rooted in a particular view of assumed future developments, and corporate history culture is therefore dynamic.

History management includes all the intentional corporate activities in the everyday use of history in business environment. In this article, I mostly consider one specimen group of corporate history culture: commissioned company history books and other published historiographical representations of a company's past. In addition, other forms of oral and written histories were used for management purposes in Porin Puuvilla Oy.

In Finland the golden era of commissioned company histories began in the 1920s. This is best understood within the context of Finnish industrial and economic history. The era of industrial capitalism in Finland can be regarded as lasting from the mid-19th up to the mid-20th century, which started with a major institutional change in the 1860 s. It was also an era of industrialisation and liberalisation, in which the most important industries were forestry and textile industry (Ojala \& Karonen 2006: 106, 124). Many Finnish industrial corporations reached the golden age of fifty in the 1920s and 1930s. The attainment of this temporal milestone thus evoked a demand for commissioned company histories.

Between the years 1920 and 1949, more than 900 Finnish company histories and other company studies were published (Karonen \& Lamberg \& Ojala 2000a: 50). Another highpoint in the commissioning of business histories was the 1980s and 1990s. 
From the early 1920s onwards, many Finnish companies hired a professional historian to write a commissioned company history. Some of the writers were professors at Finnish universities, and a few of the early Finnish company histories were of relatively high quality. However, neither commissioned company histories, nor the other genres of business history, were initiated from inside of the universities. An academic discipline of analytical economic history of business was not previously known anywhere in the world before the late 1920 s, and it is still rare in Finland in the current decade. Most company histories, commissioned or otherwise, are written under the supervision of the commissioner, in order to tell the story of one single enterprise. In Finland the writers of these early commissioned company histories came from various fields of research and education. ${ }^{10}$

For example, there were six cotton companies in Finland in the 1930s. All of them had their histories written at least once or twice before the 1970s. The commissioned company histories of Finnish cotton companies were written by historians with relatively high education. The most venerable cotton company in Finland, Finlayson Oy in Tampere, founded in 1820, was the first to commission a company history. When the company celebrated its centennial in 1920, an 18-page chronological presentation of the company's past was published anonymously, as the era of complete commissioned company histories had not yet begun.

In the university town of Turku, in the early 1930s, John Barker's Cotton Factory commissioned professor Einar Juvelius to write a history of the company covering the years 1847-1933 (Juvelius 1933). Kyösti Valfrid Kaukovalta, a trained economist and journalist, for his part, wrote the history of the Forssa Cotton Factory for the period of 1847-1934 (Kaukovalta 1934). Matti Sadeniemi, a specialist and researcher of Finnish linguistics, wrote the history of Tampereen Puuvillateollisuus Osakeyhtiö (Tampere Cotton Industry Company) for the period of 1897-1934 ${ }^{11}$ (Sadeniemi 1937). In 1938, Finlayson published a new commissioned company history (Lindfors 1938). The book covered the first 87 years of the Finlayson Company. The second part of this work was intended to cover the period from 1908 to 1938, but it was never completed.

Porin Puuvilla Oy, the object of my case study, ordered a commissioned company history of its first 50 years in 1947 (Stjernchantz 1949a; 1949b). Vaasan Puuvilla Oy (Vaasa Cotton Company) received a commissioned history of its first (and last) 100 years in 1957 (Nikula 1957). The histories of the Tampere Cotton Industry Company and the Vaasa Cotton Company were commissioned just before the companies were merged into Finlayson $\mathrm{Oy}$. 


\section{HISTORICISING THE PAST OF PORIN PUUVILLA OY}

As in many other Finnish companies, the first commissioned company history of Porin Puuvilla Oy was intended to mark a temporal milestone of 50 years.

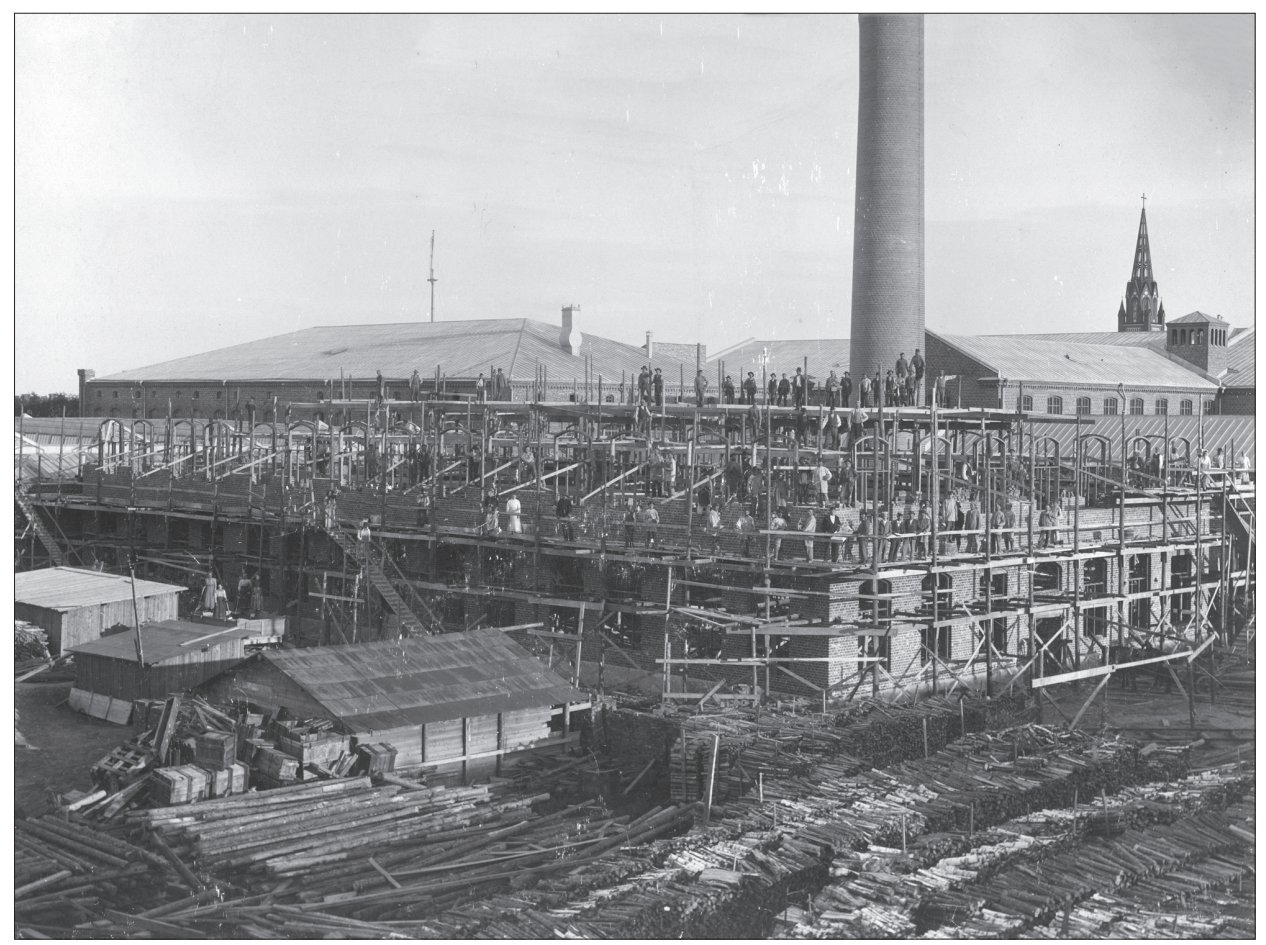

Figure 1. The building site of the Pori Cotton Factory in 1899. Photograph by SMA.

The history of Porin Puuvilla Oy was ordered from a trained historian and journalist Göran Stjernschantz in 1947. The writer had studied political sciences and history, held a master's degree, and was chief editor of Mercator: Tidskrift för Finlands näringsliv (Mercator: Journal for Finnish Business Life) (Stjernschantz 1993: 42-44). In his memoirs Stjernschantz describes his career, but does not refer to his incidental occupation as a commissioned historian of the said cotton company. Perhaps he did not consider it worth mentioning. He nevertheless points out some of his other commissioned books in his memoirs (ibid.: 111, 250-255). 
The one-volume company history Aktiebolaget Björneborgs bomull 1898-1948 (Pori Cotton Company in 1898-1948) was written in Swedish and it was ready to be published in 1948. The translated Finnish version of same book followed in 1949 (Stjernschantz 1949b). The work had 318 pages, but contained no list of references. A company history of the 1940s was written in order to meet the needs of the company. It was produced mostly of the materials from the company archive and the process was conducted under the observation and control of a company representative. The book is primarily a story of how the company managed to survive in the struggle in the Finnish cotton market. However, it contains many reliable details about how the factory was developed, mechanised and directed.

The work did not pass any kind of academic review process and Stjernschantz, for his part, was not a free academic historian in the modern sense. Two members of the company board of Porin Puuvillatehdas Oy, directors Rafael von Frenckell ${ }^{12}$ and Åke Gartz, supervised the research and writing process of the commissioned history, and also commented on the manuscript. Rafael von Frenckell was merely correcting some facts, but Åke Gartz was aiming at conducting the whole process of writing. ${ }^{13}$ Gartz himself wrote: "I think we must remove from this manuscript all such notions that enable malicious actions or the provoking of scandals". ${ }^{14}$

In Finnish business life archives, ELKA, I found a folder labelled “Av magister Göran Stjernschantz sammanbragt material för historiken: Ab Björneborgs Bomull 1898-1948" (Material collected by M.A. Göran Stjernschantz for a history of Pori Cotton Ltd. 1898-1948). The folder contained the writer's original notes and an original manuscript of the company history. On top of the files there were several sheets with statistical data about textile industry in general, and, particularly, about Porin Puuvilla Oy. Under the statistical data there were several sources concerning the shortages of raw materials in Finland during the First World War: telegrams, letters and hand-written notes on some Finnish newspaper articles published in 1916 and 1917. Under these sources was a collection of statistics and copies of different official data collection forms concerning the cartelisation of the cotton industry and cotton trading.

Gartz removed some parts of the manuscript. One of the removed parts contained a description of the bonus system applied in the company between the years 1918 and 1919. In 1919, the bonus system had been found to be illegal. This controversial incident had been reported in the Finnish newspaper Suomen Sosiaalidemokraatti (Finnish Social Democrat) on June 11, 1920, and also in other newspapers later on. In 1927, the Supreme Court of Finland rendered their final decision in the case. The company board members Jusélius, Ramberg, Sundell, Lindqvist and Petrell were fined and they had to reimburse 


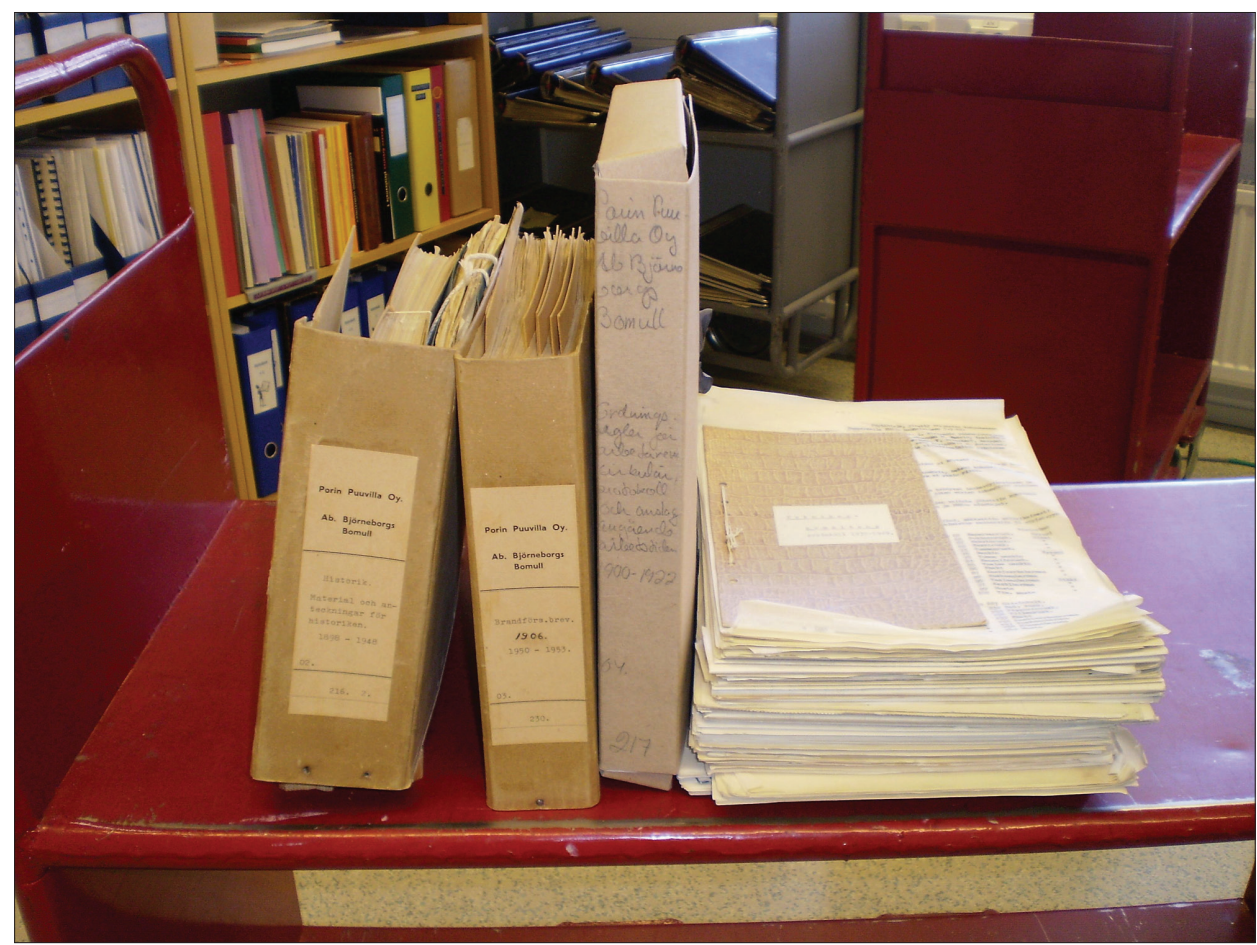

Figure 2. The raw drafts of a commissioned company history: notes and sources from 1947 to 1948 of historian Göran Stjernschantz for the corporate history of Porin Puuvillatehdas Oy, photographed in the Central Archives for Finnish Business Records. Photograph by Anna Sivula 2010.

the state a considerable amount of money for the taxes they had left unpaid during the illegal bonus system. Åke Gartz had carefully crossed out the names of the convicted directors in the manuscript copy. I could only see the removed names with the aid of a light box. I regard this small incident as a reminder of the history management strategy of the company.

Göran Stjernschantz's Porin Puuvilla Oy 1898-1948 was a company history in its own time. The society surrounding the company was only considered to the extent that was necessary to understand the developments within the company. The sources of interpretation were primarily based on company records. Furthermore, some of the early records were lost. The writer had also interviewed the managing director of the company. In the foreword and conclusion of his book, the author praised the two first managing directors of the Porin Puuvilla Oy for their supreme managerial abilities. He thanked the managing director Johan Ek (among some others) for his help. In the conclusion, 
the writer reiterated that the company had been able to pay a good amount of dividends to its owners. On the final page, he emphasised that it was a good policy to invest a considerable amount of the profits in the company in order to continue its successful development. The writer also hoped that the lessons of history learnt by Porin Puuvilla Oy would be instructive for future industrial entrepreneurs and business investors (Stjernschantz 1949b: 9-10, 287-290). Historia magistra vitae est.

The vocabulary and plot of Stjernschantz's book are interesting: according to the author, during the era of the cartelisation of the Finnish cotton industry, the company was "fighting" and "resisting the strong enemy", it "made attacks and counterattacks" and finally "survived, but lost its independence" (Stjernschantz 1949b: 206, 208, 213, 225-226). In the Finland of 1948, these expressions had a specific undertone.

The plot of the story was built so as to tell about a small but resilient company, struggling for its life against the cartelisation process. ${ }^{15}$ After the Second World War, the historical self-understanding of a company was built on the same narrative structure as the Finnish self-identification of the late 1940s: having lost the war, but having won the parry. The supposed Finnish stakeholder was able to read the code. In Finland the defeat of the Finns against the Soviet Union in the Second World War was largely considered a victory, and Finns have a specific expression for this defeat: "torjuntavoitto", a "repelling victory", or a "preventative victory".

After the first history of Porin Puuvilla Oy, the company commissioned two more histories before the story of the company ended. These were published in 1958 and 1973, respectively. Like the first one, they were supervised by the commissioner. ${ }^{16}$ At the time, no independent historical consultant was used in the production process of a commissioned company history, although the Tilaushistoriakeskus (The Finnish Centre of Commissioned Histories) had been founded in 1933. The centre functioned under the name of Paikallishistoriallinen toimisto (The Agency of Local History). Today the Finnish Tilaushistoriakeskus assists both writers and commissioners of company histories, but from the 1940 s to 1970 s this agency was only involved in consulting the writers of local and municipal histories. ${ }^{17}$ The three writers of the commissioned company histories of Porin Puuvilla Oy, Stjernschantz, Zilliacus and Metsä, received the assignment via their personal networks.

The three history books are different from each other, as concerns their communicative functions. Stjernschantz's book (1949a) was written to mark the temporal milestone of 50 years. It was mostly directed at the external stakeholders of the company. One of the chapters was, however, targeted at the internal communication of the company: it was concerned with the human 
resources policy, listed all the benefits of the employees, and emphasised the progressive nature of this policy (Stjernschantz 1949b: 271-286).

The second corporate history of the Pori Cotton Factory, published in 1958, was completely aimed at external communication. It was a manifestation of a typical use of a corporation's own history to strengthen the brand and polish the corporate image; however, the employees were completely absent from the pages. Instead, there were machines and manufactured products along with only a few pages of text. The remainder of the book was filled with colourful and, at the time, expensive pictures.

The final representation of the company's past was published in 1973 (Metsä 1973) and was directed at an internal audience. It was published 25 years after the completion of Stjernschantz's work, and 10 years after the visual story of the modern Porin Puuvilla Oy. It was written by a local journalist Tapio Metsä and completed for the 75th anniversary of the company. More a leaflet than a book, this history was presented in one issue of the company staff magazine Paali ja pakka (Pile and Pack). The presentation recapped the main points of Stjernschantz's work from 1949. The years from 1948 to 1973 were added to the former story, and the narrative proceeded mechanically through the decades, while the book was comprised of more pictures than text.

The illustration of the leaflet dealt mostly with the company's workers, the plant machinery and equipment and buildings: on 77 pages of the book, there were 64 pictures of workers, 48 of which were portraits. 17 pictures were of the machines at the plant, and 11 were pictures of the exteriors of the factory buildings. However, in this historical study the workers were brought to the fore. The owners, directors, managers and products, on the contrary, were almost absent from both the text and pictures.

It seems that in the 1970 s the corporate history culture was very different from that of the late $1940 \mathrm{~s}$. This leaflet had no intention of teaching any managerial skills to the reader, nor was it made to impress the company's customers or other external stakeholders. It was written to improve the staff morale, as well as the image of the employer in the eyes of the employees. The plot of this company history followed the story formula of a saga. The success story progressed with the war- and battle-related metaphors, which had already been introduced by Stjernschantz in 1948. The plot was leading inexorably towards the company merger into the Finlayson Oy in 1973. This company history culminated in a conclusion that the merger was a "historically inevitable step". A solemn declaration followed: The history continues. The company will go on as it is now ${ }^{18}$ (Metsä 1973: 63). These hopes and dreams were not shared by the employees, who at the time were participating in illegal strikes (Sivula 2010: 36-39). 


\section{COUNTER-CORPORATE ORAL HISTORIES IN THE TIMES OF CRISIS}

The employment of textile workers in Pori started to decrease in the late 1960s, and already before the mid-1970s the staff of Porin Puuvilla Oy had become aware of the risk (Sivula 2010: 34). International depression and oil crisis were setting in, although the economic growth in Finland did not slow down until 1974 (Hjerppe 1988: 47-48). By the time that the new kind of oral history emerged, the staff of Porin Puuvilla Oy had for years been afraid of losing their jobs.

In Western Europe, textile industrial production already had, in the early 1970 s, begun to move to countries that offered cheaper labour costs. In the late 1960s and early 1970s, Finland was a country with relatively cheap labour. The growth of Finnish textile industry continued until 1976, when the crisis of the European textile industry reached Finland. The risk of unemployment was very real. The crisis struck rapidly in Pori. In 1978, Finlayson Oy already reduced the number of employers in the Pori Cotton Factory. In 1979, there were 500 unemployed textile workers in Pori (Rahikainen 2008: 22; Sivula 2010: 33-38). The number of workers in the textile industry had been declining for some years when the total number of manufacturing industry workers started to decrease in 1981, and unemployment rates in industrial towns like Pori began to rise (Hjerppe 1988: 88-89). Then a local disaster occurred at the Pori Cotton Factory in 1981: the weaving mill, one of the few recently modernised sections of the Pori Cotton Factory, was destroyed by fire. It was the most devastating factory fire in the history of the Nordic countries. The accident accelerated the deindustrialisation of the Pori Cotton Factory, which was now part of the Finlayson Company. The spinning mill was then shut down in 1985. After this, there were only some minor textile industrial activities left; the last enterprise worked for some years within the walls of an old factory building under the name of "Nonstoppers". This too was shut down in 1994, and the last textile worker left the factory that once had been a workplace for 3,000 textile industrial workers (Sivula 2010: 34-36).

The employees of the company often have their own interpretations of the company's past. In Pori, parts of this alternative corporate historiography have survived to the present day. These oral histories were published in newspapers, and some of them were written down by three students of folklore and ethnography, in 1968, the mid-70s and in $1985 .{ }^{19}$ These students did not use tape recorders. A subplot of this alternative corporate historiography grabbed my attention. It was a nostalgic story of a better past under a good manager, Johan Ek. This story exemplifies how the contents of a commissioned company history and different public and popular histories interact within corporate 
history culture. Further on, I trace the origins of the interpretative activities behind the story and clarify how the history (as a representation of the past, taking the place of what actually happened) was constructed in this case.

Back in 1919, the Pori Cotton Factory received a new manager, engineer Johan Henrik Ek (1876-1950), who led the factory during the time of the rapid growth of Finnish textile industry, from 1919 to 1950, until his death. Stjernschantz paid attention to engineer Ek's management skills. Ek was mentioned in Stjernschantz's work from 1949, but introduced merely as an acting factory manager, rather than the managing director. There was a conventional portrait of him, and a description of two pages about his career in the service of the company. Ek was mentioned here and there in the history book, in connection with his participation in several negotiations and technical decisions made by him. He was said to have been an ambitious man, skilled engineer and business negotiator, who strictly obeyed the orders of the owners, and helped the relatively small factory through the difficult time of competition. During this era, three other Finnish cotton corporations, smaller than the one in Pori, were merged into Finlayson Oy (Stjernschantz 1949b: 141, 153-217). In the company history created in 1958, Ek was not mentioned at all.

In the years 1968-1969 and 1971-1972, Timo Puustinen and Anneli Lotvomaa, two students of ethnology and folklore from the University of Turku, interviewed a total of fourteen workers from the Pori Cotton Factory for a research project on Finnish workers, financed by the Finnish Wihuri Foundation. The workers were asked about the relations between the management and the staff. A total of twelve of the fourteen respondents did not mention factory managers, but spoke of how the foremen and machine maintenance men treated common workers. There were, however, two mentions of the late manager Ek in two of the fourteen interviews. One of them stated that "Ek owned the factory and fed the workers", and the other reported that "the managers Ek and Sundell were good, but strict men". ${ }^{20}$ These notes of "the good manager Ek" were written down in 1969 and 1972.

In Metsä's history from 1973, Ek was mentioned three times. There was no photograph of him, and the earlier development of the company, including the increase of profit and production and the extensions made to buildings under Ek's management, were historicised in terms of the process, without mentioning the name of the manager. The history of the company before the year 1950 was also written with very few personal notations.

In 1976, after the merger of the company into Finlayson Oy, a local journalist Leena Teinilä-Huittinen interviewed Finlayson's local factory manager Claes Zetter for an article, published in the local newspaper Satakunnan kansa (Satakunta People) on July 30, 1976. The rubric of the article declared: "Ek laid the basis to the success of Porin Puuvilla Oy". The article was later reprinted in a 
popular local history collection. ${ }^{21}$ Zetter used Stjernschantz's work from 1949 as a source, and told the story of the manager Ek. He emphasised that Ek had been the prime mover behind the success of the factory. According to Zetter, the company had fallen into decline after Ek's time. Zetter's last comment, cited in the article, was: "Ek did take care of workers". ${ }^{22}$ Teinilä-Huittinen wrote:

During Ek's time, the Pori Cotton Factory was developing considerably. In the 1930s, when other Finnish cotton factory workers were working short weeks, manager Ek took his suitcase and went abroad to sell Pori Cotton Factory products. Due to expanded exports, the women in the factory could keep their full-time jobs. In the 1930s, Finland's largest cotton weaving mill was in Pori. Even today, Ek's era is remembered. (Teinilä-Huittinen 1978: 17)

After the publication of this article, which happened twice, more and more of the former employees of the Pori Cotton Factory began to recall that during Ek's time things had been better.

In the counter-corporative oral history, constructed during the late 1970s and early 1980s by the staff of the Pori Cotton Factory, this particular late manager became a symbol of the better past. In 1985, ethnologist Liisa Nummelin conducted five half-structured interviews for her inventory project of Pori industrial heritage. Although she did not specifically ask about managers, she was, however, deliberately told about the good manager Ek. In 1985, Ek was remembered much better than he had been in 1968-1969 or in 1971-1972: the fact that he was a "good manager who took care of the employees" was mentioned with exactly these words in four out of five interviews, and "a good but strict manager" in three out of five interviews. ${ }^{23}$

In 1994, the last textile workers left the Pori Cotton Factory building, and the era of textile industry in the town of Pori was over. Factory manager Claes Zetter, who was no longer in the service of the company, was interviewed again. The retired manager expressed his sympathy for those who had lost their jobs. Then he told a comforting story of the good manager Ek:

When Ek died in Tampere on the PMK (The National Cotton Industries Sales Association) Houses staircase after difficult negotiations in 1950, he went to heaven. The factory staff knew he had founded a brand-new factory up there. His protective spirit was, after his death, still living in the factory halls, and when a worker died, they said that he went to Ek's factory.

This quote was published in a local newspaper Satakunnan Kansa (Satakunta People) on July 1, 1994. I and my students heard this story in the early 2000s. One might ask whether the story of the good manager Ek would have ever 
emerged among the old workers of the Porin Puuvillatehdas Oy without the original source written by Göran Stjernschantz, and the transmission of the story by manager Zetter and the local newspaper.

\section{HOW DID CORPORATE HISTORY CULTURE CHANGE?}

It seems to me, in the light of my case study, that corporate history culture changed between the 1940s and 1973. The focus on representing the past of a cotton company moved from the external to the internal history management. The target group of the commissioned company history was no more the external stakeholders, but the internal personnel.

The practice of history management can be divided into two layers in terms of two questions. The first question is: Does the company use history for internal or external communication purposes? The corporate use of histories and traditions has been previously researched from the point of view of both external and internal communication (see, e.g., Rakob \& Burkhardt 2006: 399-407). The second question is: Does a company use external (e.g., general, national, local or other non-corporate) histories or internal, commissioned company histories, or other histories closely related to its own past? The four possible dimensions of history management are an outcome of the two questions above. They can be observed in the four-field below.

\begin{tabular}{|l|l|l|}
\hline $\begin{array}{l}\text { External } \\
\text { communication }\end{array}$ & $\begin{array}{l}\text { External histories } \\
\text { of history is represented } \\
\text { and used in products, } \\
\text { corporate imageries } \\
\text { (e.g., brands and } \\
\text { commissioned } \\
\text { company histories) and } \\
\text { marketing. }\end{array}$ & $\begin{array}{l}\text { Internal histories } \\
\text { history in products, } \\
\text { corporate imageries } \\
\text { (e.g., brands and } \\
\text { representations of the } \\
\text { company past) and } \\
\text { marketing. }\end{array}$ \\
\hline $\begin{array}{l}\text { Internal } \\
\text { communication }\end{array}$ & $\begin{array}{l}\text { General or other types of } \\
\text { history, e.g., case studies } \\
\text { of business history, } \\
\text { are used for internal } \\
\text { management and } \\
\text { leadership purposes. }\end{array}$ & $\begin{array}{l}\text { Company uses its own } \\
\text { history for internal } \\
\text { management and } \\
\text { leadership purposes. }\end{array}$ \\
\hline
\end{tabular}


In this case study I primarily focus on the corporate use of internal histories. The external histories were used in order to explain the economic success and failures of the company. The explanations based on external histories were used for both internal and external communication purposes. The company explained in its external history from 1973 the coming merger in 1974.

The use of internal histories is observed here from the point of view of both external and internal communication. The corporate history from 1948 was similar to an extended version of an annual report. It was written primarily in order to convince the external stakeholders that the company was growing and making a profit. ${ }^{24}$ The writer offered his book to other companies for internal management and leadership purposes.

The internal history of a company was used for internal communication by Stjernschantz (1949b) in the chapter that introduced the company's human resources politics, and in Metsä's book from 1973, which left the management and the owners in the shadow of the merited workers. External history was used in the same work for external communication, explaining the selling of the whole business due to the development of the world market economy and the historical long-term trend of industrial mergers. According to Metsä (1973), the selling of what was practically a family-business-based factory to the large business group of Finlayson Oy, was business as usual.

Claes Zetter used the company's internal history for external communication in the good manager Ek's case, but it is difficult to ascertain how corporate this history cultural act in the final analysis was. Some other than corporate motives can surely be pointed out. This no-mans-land of telling unauthorised company histories needs further research from the point of view of history management. What is an acting manager of a factory actually doing, when he, in local newspapers, refers to the better times of the factory under the management of one of his predecessors? From the point of view of history management, the use of public media refers to external communication. A manager who was going to retire soon used internal history in suggesting some kind of return to the past management practices.

Eighteen years later, when the already retired manager relayed his comforting story, the action itself was different from that of 1976 , as the factory was already gone. There was no corporate context left for managing history. The other members of the heritage community had begun to share the constructed Ek as a symbol of the better past. It was perhaps an act of reminiscence, or even an apology, but not an act of history management.

The interviewed workers, the interviewing ethnologist, and the journalist, who in the late 1960s, the 1970s and the mid-1980s, consolidated the story of the good manager Ek, constructed together, more or less deliberately, a counter- 
corporate history of the Finlayson Oy's cotton factory in Pori. This history was motivated with a touch of nostalgia. The story was filled with longing for the patronising, authoritarian, almost patriarchal ${ }^{25}$ practices of the management culture of the imagined past. This kind of inclusive and exclusive actions of a post-corporate heritage community, motivated perhaps with a shared nostalgia, demand further research.

\section{DISCUSSING THE CORPORATE HISTORY CULTURE IN THE CONTEXT OF RETRO AND NOSTALGIA}

How does the corporate history culture of my case look in the context of some key concepts of the current retro- and nostalgia-related discussions in cultural studies? Were there any early signals of these trends?

The story of Porin Puuvillatehdas Oy ended before the era of retromania began. The University Consortium in Pori has, since the late 1990s, reused the buildings, and there might be some retro aspects in the reuse process. These retro aspects are currently emerging, but they do not belong to the corporate history culture of Porin Puuvilla Oy, but instead to the corporate history culture of the University Consortium in Pori (Suominen \& Sivula 2012).

Most of the academic discussions about the retro turn have been carried out in terms of the pervasive cultural explanation of nostalgia. The emphasis on nostalgia has almost silenced the other possible explanations for the increasing historical interest in the 21st century. Nostalgia is one of the important factors behind present-day historic-cultural activity. It nurtures the growing demand for histories, but does it really cause or explain the demand for new histories? When it comes to the main stream of corporate history culture, the answer seems to be negative.

In my case study some traces of nostalgia were found in the context of the almost or entirely lost corporation. I did not find any traces of the "consumeristsimulational nostalgia". The emergence of an inclusive narrative about the good manager Ek consolidated the post-corporate heritage community of Porin Puuvilla Oy. This process can be understood in terms of the first-order nostalgia of Davis. I did not find traces of the second- or third-order nostalgia. The emergence of a counter-corporate history can, to some extent, be understood in terms of Boym's restorative nostalgia. Another question is how useful an element of explanation that nostalgia is when it comes to the whole context of corporate history culture? According to cultural historian Anu Koivunen, the discourse of nostalgia is "saturated with the idea of the crisis", and nostalgia is often presented as both the diagnosis and remedy for the crisis. Koivunen 
asks: "If the phenomenon of nostalgia is so overwhelming, what then happens to the analytic power of the concept?" (Koivunen 2001: 325)

The main stream of corporate history management, in a functioning company, had only little to do with nostalgia. When active, the company was not longing for the lost home. It was ordering histories from professional historians for some other reason. In their annual or quarterly reports, companies are not yearning for yesterday either. History was not used to escape from the present to the past. In corporate history culture one must be careful with the use of explanatory nostalgia. Nostalgia is rooted in corporate history culture like in any other history culture, but if it is cut off, the historic-cultural stage is not emptied of actors, aims or ambiences. The researcher of history management should pay attention to how the historical facts, presented in company histories, are constructed and selected. This fact does not solely fill the whole historiccultural stage either, but with a sentiment of reliability, it plays an important role in both the structure and actions of history management.

\section{ABBREVIATIONS}

ELKA - Suomen Elinkeinoelämän Keskusarkisto (Central Archives of Finnish Business Records)

SMA - Satakunnan Museon Arkisto (Satakunta Museum Archives)

SK - Satakunnan Kansa (a leading newspaper in the Finnish province of Satakunta)

TYKL - Turun yliopiston kulttuurien tutkimuksen laitos (Institute of Cultural Studies, Turku University)

\section{NOTES}

1 "History culture" is a translation of the Finnish "historakulttuuri" or Swedish word "historibruk". On the concept, see Salmi 2001 and Aronsson 2004.

2 On the development of academic business history: Fridensen 2008. Fridensen emphasises the importance of the three scales of business history: the microhistorical, the mesohistorical and the macrohistorical. See also Coleman 1992, pp. 203-207, on the emergence of business history in Great Britain, where the Business History Unit was established between 1977 and 1979.

3 See also Delahaye et al. 2009: 9.

4 Ponzoni and Boersma deal with a Dutch case. It is uncertain whether their results can be generalised. 
5 In Business History Review there seems to be a growing interest in family firms and other kinds of company historical cases. Business History Review http://journals. cambridge.org/action/displayIssue?jid=BHR\&tab=currentissue; no longer available.

6 This kind of "art or science" discussion was going on in the 1970s and 1980s, when historians tried to identify their profession among the other social scientists. See, for example, Marwick 1970, Iggers 1975, Hexter 1979, Stanford 1987.

7 On the excluding of company histories from the academic tradition Finnish business history in 2006, see, for example, University of Helsinki: Yhteiskuntahistorian johdantokurssi. Taloushistoriaosio. Luento IV, 2. (Introduction to Social History. Economic History. Lecture IV, slide 2). http://www.slideserve.com/chalice/ yhteiskuntahistorian-johdantokurssi-taloushistoriaosio-luento-iv, last accessed on December 17, 2013.

On the other hand, according to Walter Friedman and Jeffrey Jones, "traditional, managerial, firm-centered approaches" and courses organised around issues such as the evolution of a single firm, are one of the four common methodological approaches to business history. See Guide to Business History Courses Worldwide 2012: 4-6.

The other three common methodological approaches are the history of capitalism as a social, cultural and political phenomenon; history of the traditional sectors of financing and banking; and an approach structured around the words "technology" and "innovation".

8 Coleman cites the correspondence related to the founding of the British Business History Unit in the 1970s and 1980s.

9 On previous interpretations of "history management" or "management of history" see, e.g., Heinemann 2006 and Suominen \& Sivula 2012.

${ }^{10}$ For example, Hjalmar Tallqvist, who wrote the history of Vakuutus-osakeyhtiö Fennia 1882-1932 (1932), was a professor of physics. Eric Bahne, who in the late 1940s wrote a cultural-historically oriented 100-year history of P.C. Rettig \& Co, was a high school principal in Turku.

11 The iron and linen company Tampella (Tammerfors Linne- \& Jern-Manufaktur AktieBolag) bought the cotton factory in Lapinniemi in1934 and Tampereen Puuvillateollisuus Osakeyhtiö was merged into Tampella. The company history was commissioned on the eve of the merger.

12 Stjernschantz mentions Rafael von Enckel in his memoirs, and describes him as a "mighty man behind the scene" (Stjernschantz 1993: 155). Gartz is not mentioned. Neither of the supervisors is introduced in the foreword of the commissioned history, but there are pictures of them, presented as board members, on pages 254 and 255 of Stjernschantz 1949b.

13 The commented manuscript: Porin Puuvilla Oy. Ab Björneborgs Bomull. A.B. Björneborgs Bomulls korrektur-exemplar av historiken (...) jämte förslag om diverse korrigeringar. Porin Puuvilla (ELKA).

14 The original Swedish citation: "Jag anser att detta också bör göras, ty om man låter redogörelsen inflyta i så utförligt skick som nu i manuskriptet, så ger man åt illvilliga element direkt material som kan utnyttjas i skandaliseringssyfte.” Porin Puuvilla 
Oy. Ab Björneborgs Bomull. Historik. Material och anteckningar för historiken. Åke Gartz till Direktör J. H. Ek (ELKA).

${ }^{15}$ On the cartelisation of Finnish cotton industry see Kallioinen 2006.

${ }^{16}$ See Zilliacus \& Aho 1958, and Metsä 1973.

17 According to Marja Pohjola's e-mail reply (08.10.2013) to my inquiry, Paikallishistoriallinen toimisto was not at the time offering any academic review services to commissioned company histories. Marja Pohjola has been a secretary of the organisation since the year 1979 .

${ }^{18}$ Original citation: "Porin Puuvillan viimeaikaisten voimakkaiden ja syvällisten kehitystoimien, joista edellä on kerrottu, jatkoksi yhtyminen Finlaysoniin on täysin johdonmukainen askel. Porin puuvillan vahvojen tuotantoyksiköiden historia ei pääty tehtaan 75-vuotisjuhliin, vaan jatkuu nykyisinä, omaleimaisesti toimivina kokonaisuuksina - osana suomalaista ja satakuntalaista teollisuustoimintaa" (Metsä 1973: 63).

19 Original notes of the interviews made by Timo Puustinen (1969) and Anneli Lotvomaa (1972) are preserved in the Turku University TYKL-archive. Puustinen 1969 (KTL 656); Lotvomaa 1972 (KTL 777), copies of these and the original notes of Liisa Nummelin (1985) are preserved in the Satakunta Museum Archives (SMA).

${ }^{20}$ Porin Puuvilla. Teollisuustyöväen haastattelut 1969 (Puustinen), 1972 (Lotvomaa) and 1985 (Nummelin). SMA.

${ }^{21}$ Teinilä-Huittinen, Leena 1978. Porin Puuvillan menestyksen perusta J. H. Ekin aikana. The article was first published anonymously in the newspaper Satakunnan Kansa on July 30, 1976, and reproduced in Vanha Pori (1978), edited by Leena Teinilä-Huittinen and Raimo Huittinen, Keuruu: Otava.

${ }^{22}$ In the late 1970s Finnish newspaper articles were mainly published without the name of the writer. News about the redundancies, lay-offs and losses at the Porin Puuvillatehdas, now owned by Finlayson Oy, in Satakunnan Kansa, SK 17.1.1976, SK 30.7.1976, SK 10.2.1977, SK 4.4.1977 and SK 17.3.1978.

${ }^{23}$ Porin Puuvilla. Teollisuustyöväen haastattelut 1985 (Nummelin). SMA.

${ }^{24}$ Good examples of a convincing serial or comparative presentations in: Stjernschantz 1949a, pp. 196, 220 and 267, and tables (303-311) concerning the machinery, staff, production, assets and liabilities, depreciation and profit, dividends and salaries, and finally a table of the distribution of the company gross income to salaries, taxes, profit and dividends between 1920 and 1947.

${ }^{25}$ Industrial paternalism refers to the practice of industrial enterprises, instead of their owners, providing welfare services to their employees. Within this new, 19th-century managerial setting, the older authoritarian practices remained in everyday management. The transformation from patriarchal order to industrial paternalism was slow. See, for example, Karonen 2002: 259. 


\section{ARCHIVAL SOURCES}

\section{Central Archives of Finnish Business Records, Elinkeinoelämän}

\section{Keskusarkisto, Mikkeli, Finland}

Porin Puuvilla Oy. Ab Björneborgs Bomull. Historik. Material och anteckningar för historiken. 1898-1948. [A History. Material and Notes for a History. 1898-1948.]

Porin Puuvilla Oy. Ab Björneborgs Bomull. A.B. Björneborgs Bomulls korrektur-exemplar av historiken (...) jämte förslag om diverse korrigeringar. [A Manuscript of a History: Suggestions for Corrections.]

Porin Puuvilla Oy. Ab Björneborgs Bomull. Historik. Material och anteckningar för historiken. Åke Gartz till Direktör J. H. Ek. [Material and Notes for a History. Åke Garts to Director J. H. Ek.]

\section{Satakunta Museum Archives, Pori, Finland}

Porin Puuvilla. Teollisuustyöväen haastattelut. [Interviews of industrial workers.] Puustinen Timo (1969), Lotvomaa, Anneli (1972) and Nummelin, Liisa (1985). Originals of Nummelin 1985, copies of Lotvomaa 1972 and Puustinen 1969.

Original notes of Puustinen (1969) and Lotvomaa (1972): Turku University TYKLarchive. Puustinen 1969 (KTL 656); Lotvomaa 1972 (KTL 777).

Photographic archive Valokuva-arkisto.

\section{Archives of Satakunnan Kansa newspaper, Pori}

SK 17.1.1976

SK 30.7.1976

SK 10.2.1977

SK 4.4.1977

SK 17.3.1978

SK 1.7.1994

\section{REFERENCES}

Appadurai, Arjun 1996. Modernity at Large: Cultural Dimensions of Globalization. Minneapolis: University of Minnesota Press.

Aronsson, Peter 2004. Historiebruk. Att använda det förflutna. [History Works. Use of the Past.] Lund: Studentlitteratur.

Bloch, Marc 1937. Que demander a l'histoire? Bulletin. Centre polytechnicien d'études économiques, No. 34, pp. 15-22. 
Bloch, Marc 1997 [1949]. Apologie pour l'histoire ou Métier d'historien. Paris: Armand Colin. First edition available at http://classiques.uqac.ca/classiques/bloch_marc/ apologie_histoire/bloch_apologie.pdf, last accessed on December 18, 2013.

Boym, Svetlana 2001. The Future of Nostalgia. New York: Basic Books.

Coleman, Donald C. 1992. Myth, History and the Industrial Revolution. London \& Rio Grande: Hambledon Press.

Davis, Fred 1979. Yearning for Yesterday: A Sociology of Nostalgia. New York: The Free Press.

Delahaye, Agnès \& Booth, Charles \& Clark, Peter \& Procter, Stephen \& Rowlinson, Michael 2009. The Genre of Corporate History. Journal of Organizational Change Management, Vol. 22, No. 1, pp. 27-48. http://dx.doi.org/10.1108/09534810910933898.

Fridenson, Patric 2008. Business History and History. In: Geoffrey Jones \& Jonathan Zeitlin (eds.) The Oxford Handbook of Business History. Oxford: Oxford University Press. http://dx.doi.org/10.1093/oxfordhb/9780199263684.003.0002.

Guide to Business History Courses Worldwide 2012. Edited by Walter A. Friedman \& Jeffrey Jones. Harvard: Harvard Business School. Available at http://www.hbs. edu/businesshistory/Documents/00-final-volume-2-report-Oct\%2017-2012-withcover.pdf, last accessed on December 17, 2013.

Heinemann, Stefan 2006. Grands récits nouveaux. Reflexionen zur Geschichte von Unternehmen und Marken an der Grenze von Philosophie und Ökonomie. In: Nicolai O. Herbrand \& Stefan Röhrig (eds.) Die Bedeutung der Tradition für die Markenkommunikation. Konzepte und Instrumente zur Ganzheitlichen Ausschöpfung des Erfolgspotenzials Markenhistorie. Stuttgart: Edition Neues Fachwissen GmbH, pp. 77-104. Available at http://history-management.com/BeitragHM.pdf, last accessed on December 16, 2013.

Hexter Jack H. 1979. On Historians: Reappraisals of Some of the Makers of Modern History. Harvard: Harvard University Press.

Hjerppe, Riitta 1988. Suomen talous 1860-1985: Kasvu ja rakennemuutos. [Finnish Economy: Growth and Structural Change in 1860-1985.] Helsinki: Suomen Pankin Kirjasto. Available at http://www.suomenpankki.fi/pdf/43549.pdf, last accessed on December 18, 2013.

Iggers, Georg G. 1975. New Directions in European Historiography. Middletown, CT: Wesleyan University Press.

Juvelius, Einar W. 1933. John Barkerin puuvillatehdas 1843-1933. [John Barker's Cotton Factory 1843-1933.] Turku: John Barker Oy.

Kallioinen, Mika 2006. Kesytetty kilpailu. Yhteistyö ja kartellisoituminen Suomen puuvillateollisuudessa 1900-1939. [Tamed Competition: Cooperation and Cartelisation in the Finnish Cotton Industry, 1900-1939.] Turku: Turun yliopisto \& Suomen historia.

Karonen, Petri 2002. Patriarkaalisen järjestyksen monet todellisuudet. [The Different Forms of Patriarchal Regime.] In: Piia Einonen \& Petri Karonen (eds.) Arjen valta. Suomalaisen yhteiskunnan patriarkaalisesta järjestyksestä myöhäiskeskiajalta teollistumisen kynnykselle (v. 1450-1860). Helsinki: SKS, pp. 255-259.

Karonen, Petri \& Lamberg, Juha-Antti \& Ojala, Jari 2000a. Yritykset muuttuvat, muuttuuko historiantutkimus. Yrityshistorioista yrityksen taloushistoriaksi. [Busi- 
nesses are Changing, What about Historiography?] Historiallinen aikakauskirja, Vol. 1, pp. 47-65.

Karonen, Petri \& Lamberg, Juha-Antti \& Ojala, Jari 2000b. Alemmuuskompleksia vai ammattiylpeyttä? [An Inferiority Complex or Pride?] Historiallinen aikakauskirja, Vol. 3, p. 236.

Kaukovalta, Kyösti V. 1934. Forssan puuvillatehtaan historia 1847-1934. [The History of Forssa Cotton Factory 1847-1934.] Forssa: Oy Forssa Ab.

Kipping, Matthias \& Üsdiken, Behlül 2008. Business History and Managerial Studies. In: Geoffrey Jones and Jonathan Zeitlin (eds.) The Oxford Handbook of Business History. Oxford: Oxford University Press. doi: 10.1093/oxfordhb/9780199263684.003.0005.

Koivunen, Anu 2001. Takaisin kotiin. [Back Home.] In: Anu Koivunen \& Susanna Paasonen \& Mari Pajala (eds.) Populaarin lumo: Mediat ja arki. Turku: Turun yliopisto, Mediatutkimuksen laitos, pp. 324-350.

Lindfors, Gustav 1938. Finlaysonin tehtaat Tampereella I: 1820-1907. [Finlayson's Factories in Tampere I: 1820-1907.] Helsinki: Finlayson Oy.

Lipartito, Kenneth 2008. Business Culture. In: Geoffrey Jones and Jonathan Zeitlin (eds.) The Oxford Handbook of Business History. Oxford: Oxford University Press. http://dx.doi.org/10.1093/oxfordhb/9780199263684.003.0025.

Marwick, Arthur 1970. The Nature of History. London: Macmillan.

Metsä, Tapio 1973. Porin Puuvilla Oy - Ab Björneborgs Bomull: vuosina 1898-1973. Paali ja pakka. [Pile and Pack.] Porin Puuvilla Oy:n 75-juhlavuotisnumero. Pori: Porin Puuvilla Oy \& Ab Björneborgs Bomull.

Nikula, Oscar 1957. Vaasan Puuvilla Oy 1856-1956. [Vaasa Cotton Factory 1856-1956.] Helsinki: Vaasan Puuvilla Oy.

Ojala, Jari 2001: Yritys voi oppia historiasta. [An Enterprise Is Able to Learn from its History.] Historiallinen aikakauskirja [Historical Journal], Vol. 2, pp. 220-224.

Ojala, Jari \& Karonen Petri 2006. Business: Rooted in Social Capital over the Centuries. In: J. Ojala \& J. Eloranta \& J. Jalava (eds.) The Road to Prosperity: An Economic History of Finland. Helsinki: SKS, pp. 93-125.

Ponzoni, Elena \& Boersma, Kees 2011. Writing History for Business: The Development of Business History between "Old" and "New" Production of Knowledge. Management \& Organizational History, Vol. 6, No. 2, pp.123-143. http://dx.doi. org/10.1177/1744935910364050.

Rahikainen, Marjatta 2008. Mistä työväki tuli tutkimukseen ja missä se nyt on. [The Rise and Fall of the Working Class Studies.] In: Matti Hannikainen \& Pia Lohikoski (eds.) Työväki lähtee - mihin suuntaa tutkimus? Väki Voimakas, No. 21, pp. 13-27. Available at https://helda.helsinki.fi/bitstream/handle/10138/16502/ tyovaki_lahtee_vv21_2008.pdf?sequence=1, last accessed on December 18, 2013.

Rakob, Eva-Maria \& Burkhardt, Rainer 2006. Der Bosch-Zünder: Die Marke in der Marke. Die Mitarbeiterzeitung "Bosch-Zünder" ist für die Beschäftigen des Technologiekonzerns ein Stück Firmentradition zum Anfassen - und das schon seit 1919. In: Nicolai O. Herbrand \& Stefan Röhrig (eds.) Die Bedeutung der Tradition für die Markenkommunikation. Konzepte und Instrumente zur Ganzheitlichen Ausschöpfung des Erfolgspotenzials Markenhistorie. Stuttgart: Edition Neues 
Fachwissen GmbH, pp. 397-407. Available at http://history-management.com/ BeitragHM.pdf, last accessed on December 16, 2013.

Reynolds, Simon 2011. Retromania: Pop Culture's Addiction to Its Own Past. New York: Faber and Faber.

Ricoeur, Paul 2000. La mémoire, l'histoire, l'oubli. Paris: Editions du Seuil.

Robertson, Roland 1992. Globalization: Social Theory and Global Culture. London: SAGE.

Sadeniemi, Matti 1937. Tampereen Puuvillateollisuus Osakeyhtiö 1897-1934. [Tampere Cotton Industry Ltd. 1897-1934.] Tampere: Tampereen Puuvillateollisuus Osakeyhtiö.

Salmi, Hannu 2001. Menneisyyskokemuksista hyödykkeisiin: Historiakulttuurin muodot. [From Experienced Past to Commodities: Forms of History Culture.] In: Jorma Kalela \& Ilari Lindroos (eds.) Jokapäiväinen historia, Helsinki: SKS, pp. 134-149.

Sivula, Anna 2010. Työn paikasta teollisen kulttuurin perinnöksi. Porin Puuvillatehdas 1898-2010. [From a Venue of Work into Industrial Heritage: The Pori Cotton Mill 1898-2010.] Tekniikan Waiheita, No. 3, pp. 21-46.

Sivula, Anna 2013. Yrityksen kielestä teollisuusmuistojen kieleksi. Ruotsinkielisyyden merkkejä Porin puuvillatehtaan dokumenteissa. [From the Company Language to the Language of Industrial Memories: Traces of Swedish in the Documents of Pori Cotton Factory.] In: Riina Haanpää \& Outi Tuomi-Nikula (eds.) Ruotsinkielisten kulttuuriperintöä. Turun Yliopisto, Kulttuurituotannon ja maisemantutkimuksen julkaisut 41. Pori: Turun yliopiosto, pp. 139-156.

Stanford, Michael 1987. The Nature of Historical Knowledge. Oxford: Blackwell.

Stjernschantz, Göran 1949a. Aktiebolaget Björneborgs bomull 1898-1948. [Pori Cotton Factory 1898-1948.] Björneborg: Björneborgs bomull Ab.

Stjernschantz, Göran 1949b. Porin puuvilla 1898-1948. [Pori Cotton Factory 1898-1948.] Pori: Porin Puuvilla Oy.

Stjernschantz, Göran 1993. Bilagor till ett bokslut. [Annex to the Financial Statements.] Helsingfors: Söderström.

Suominen, Jaakko 2008. The Past as the Future. Nostalgia and Retrogaming in Digital Culture. The Fibreculture Journal, Issue 11. Available at http://eleven. fibreculturejournal.org/fcj-075-the-past-as-the-future-nostalgia-and-retrogamingin-digital-culture/, last accessed on December 19, 2013.

Suominen, Jaakko \& Sivula, Anna 2012. Retrovaatiot - ajatuksia teknologian historian hyödyllisyydestä. [Retrovations: Rethinking the History of Technology.] Tekniikan waiheita, Vol. 4. Available at http://www.ths.fi/Suominen-ja-Sivula_TW-4-2012. pdf, last accessed on December 17, 2013.

Teinilä-Huittinen, Leena 1978. Porin Puuvillan menestyksen perusta J. H. Ekin aikana. [The Success of the Pori Cotton.] First published anonymously in Satakunnan Kansa on July 30, 1976; reproduced in: Leena Teinilä-Huittinen and Raimo Huittinen (eds.) Vanha Pori. Keuruu: Otava.

Vesikansa, Jyrki 2000a. Historioitsijoiden alemmuuskompleksin heijastumia. [Reflections of the Inferiority Complex of Historians.] Historiallinen aikakauskirja, Vol. 2, pp. 161-163. 
Yhteiskuntahistorian johdantokurssi. Taloushistoriaosio. Luento IV, 2. Helsingin yliopisto. [Introduction to Social History: Economic History. Lecture IV, slide 2. University of Helsinki.] Available at http://www.slideserve.com/chalice/ yhteiskuntahistorian-johdantokurssi-taloushistoriaosio-luento-iv, last accessed on December 17, 2013.

Zilliacus, Benedict \& Aho, Claire 1958. Porin Puuvilla Oy - Ab Björneborgs Bomull 1898-1958. Pori: Porin Puuvilla Osakeyhtiö. 